\title{
Quantification of trace transformation products of rocket fuel unsymmetrical dimethylhydrazine in sand using vacuum-assisted headspace solid- phase microextraction
}

\section{Aray Zhakupbekova}

Al-Farabi Kazakh National University Faculty of Chemistry and Chemical Technology

Nassiba Baimatova ( $\sim$ baimatova@cfhma.kz)

Al-Farabi Kazakh National University https://orcid.org/0000-0002-0631-3425

Elefteria Psillakis

Technical University of Crete School of Environmental Engineering

Bulat Kenessov

Al-Farabi Kazakh National University Faculty of Chemistry and Chemical Technology

\section{Research Article}

Keywords: Vacuum-assisted headspace solid-phase microextraction, GC-MS, soil analysis, transformation products, dimethylhydrazine, rocket fuel

Posted Date: March 22nd, 2021

DOI: https://doi.org/10.21203/rs.3.rs-300270/v1

License: (c) (1) This work is licensed under a Creative Commons Attribution 4.0 International License. Read Full License

Version of Record: A version of this preprint was published at Environmental Science and Pollution Research on January 14th, 2022. See the published version at https://doi.org/10.1007/s11356-02117844-1. 


\section{Abstract}

Quantification of unsymmetrical dimethylhydrazine (UDMH) transformation products (TPs) in solid samples is an important stage in monitoring of environmental pollution caused by heavy rockets launches. The new method for simultaneous quantification of UDMH TPs in sand samples using vacuum-assisted headspace solid-phase microextraction (Vac-HSSPME) followed by gas chromatography-mass spectrometry (GC-MS) is proposed. Compared to regular HSSPME, Vac-HSSPME yielded 1.3-4.8 times higher responses for NDMA, MTA and PAI. Increasing air-evacuation time from 20 to $120 \mathrm{~s}$ at $23^{\circ} \mathrm{C}$ resulted in decreased responses of analytes by $25-46 \%$. Freezing of samples $\left(-30^{\circ} \mathrm{C}\right)$ had negligible effect on responses of analytes at air-evacuation time $20 \mathrm{~s}$. The best combination of responses of analytes and their RSDs was achieved after air-evacuation of a sample $(m=1.00 \mathrm{~g})$ for $20 \mathrm{~s}$ at $23^{\circ} \mathrm{C}$, incubation for $30 \mathrm{~min}$ and 30 -min extraction at $40^{\circ} \mathrm{C}$ by Car/PDMS fiber. Vac-HSSPME provided linear calibration plots in studied ranges of concentrations with coefficients of determination ranging from 0.9912 to 0.9938 . The limits of detection for spiked sand samples varied from 0.035 to $3.6 \mathrm{ng} \mathrm{g}^{-1}$. Spike recoveries of target analytes from sand samples were $84-97 \%$ with RSDs $1-11 \%$. The developed method was successfully tested in the experiment on studying losses of analytes from open vials with model sand spiked with UDMH TPs. The developed method can be recommended for analysis of trace concentrations of UDMH TPs when studying their transformation, migration and distribution in contaminated sand.

\section{Introduction}

Unsymmetrical dimethylhydrazine (UDMH) is commonly used as a high-energy fuel of heavy-lift launch vehicles. In 2018, 47.4\% of 114 orbital launchers used fuel containing UDMH (Gunter's Space Page 2019). The total percentage of unsuccessful launches of Proton rocket launched from Baikonur cosmodrome in Kazakhstan is about 10\% (Kolesnikov 2014). Environmental pollution by highly toxic chemicals due to rocket launches is of a huge concern for every new launch. Once released in the environment, most UDMH is oxidized, e.g., by atmospheric oxygen, with a formation of many transformation products. UDMH is a toxic, carcinogenic and mutagenic compound (U.S. EPA 1984; NIOSH 1997, 2018) posing a negative impact to the environment and human health (NIOSH 1997; Carlsen et al. 2007, 2008, 2009). Trace amounts of UDMH transformation products (TPs) in soils can be detected several decades after the landing of rocket stage (Kenessov et al. 2010b, 2012; Rodin et al. 2012; Kolesnikov 2014). Up until today, more than fifty UDMH TPs were identified (Rodin et al. 2008, 2012; Kenessov et al. 2012; Ul'yanovskii et al. 2017).

Common analytical methods used for the determination of UDMH TPs in soil are based on gas (Kenessov et al. 2010b; Kosyakov et al. 2015; Ul'yanovskii et al. 2015; Bakaikina et al. 2018) and liquid (Kosyakov et al. 2014) chromatography coupled to various detectors. Conventional sample preparation methods for this type of determination are based on solvent extraction (Rodin et al. 2010; Kosyakov et al. $2014,2015)$. Despite these methods provide high sensitivity and reliability, they are quite labor-intensive and costly. 
Most prospective sample preparation methods for determination of UDMH TPs in soil samples (Kenessov et al. 2010a, 2011; Yegemova et al. 2015; Bakaikina et al. 2018; Orazbayeva et al. 2018b) are based on headspace solid-phase microextraction (HSSPME). HSSPME is a simple, low cost and environmentally friendly technique that is widely used in a variety of applications. The use of HSSPME allowed a low-cost collection of detailed information about distribution of transformation products in soil at the fall places of burned-out parts of "Proton" rockets (Kenessov et al. 2012). Quantification of UDMH TPs in soil using HSSPME is limited by matrix effects, which are common for all semi-volatile organic compounds (SVOCs) (Llompart et al. 1999, 2019; Kenessov et al. 2016). Matrix effect can be controlled using standard addition (SA) and internal standard (IS) calibrations methods (Llompart et al. 1999; Yegemova et al. 2015; Bakaikina et al. 2018), and/or minimized using derivatization, solvent extraction, addition of excess water, increase of extraction temperature and exhaustive extraction e.g., by cold fiber (Kenessov et al. 2016). High reactivity of UDMH and some of its transformation products upon contact with air and water (Buryak et al. 2004; Rodin et al. 2008, 2012; Kenessov et al. 2012) is another problem resulting in a decreased accuracy of methods based on HSSPME, particularly at elevated temperatures (Zhubatov et al. 2016; Bakaikina et al. 2017, 2018).

Brunton et al. (Brunton et al. 2001) showed a positive effect of a decreased pressure during SPME on the extraction of volatile organic compounds (VOCs) from food samples. Psillakis et al. (Psillakis et al. 2012a) investigated the pressure impact on extraction kinetics during non-equilibrium headspace SPME and established a dramatically increasing extraction rates and responses of analytes. The technique was called vacuum-assisted headspace solid-phase microextraction (Vac-HSSPME) and proved to be particularly beneficial for analytes with a low headspace-sample distribution constant (Psillakis 2017; Zhakupbekova et al. 2019). The approach was successfully applied for the quantification of polycyclic aromatic hydrocarbons (PAHs) (Yiantzi et al. 2015; Beiranvand and Ghiasvand 2017) in soil samples, PAHs (Psillakis et al. 2012a, 2013), polychlorinated biphenyls (Yiantzi et al. 2016), chlorophenols (Psillakis et al. 2012b) and UDMH TPs (Orazbayeva et al. 2018a) in water samples.

Preparing evacuated extraction vessels with solid samples is much more difficult compared to liquid samples. A liquid sample can be introduced into an evacuated vessel with a septum using a syringe (Yiantzi et al. 2016; Trujillo-Rodríguez et al. 2017). For soil, such technique cannot be used, and air evacuation is carried out in the presence of the sample (Yiantzi et al. 2015) or in specially designed extraction vessels (Beiranvand and Ghiasvand 2017; Ghiasvand et al. 2018a, b). The first approach can result in losses of analytes (Yiantzi et al. 2015; Capetti et al. 2020) while the second one requires nonstandard equipment and does not allow an automation. Orazbayeva et al. (Orazbayeva et al. 2018b) developed the method for quantification of UDMH TPs in aqueous extracts from soil samples based on Vac-HSSPME. Despite the method provides good analytical parameters ( $\mathrm{RSD} s<5 \%, R^{2}>0.991$, LODs 0.2$9 \mathrm{ng} \mathrm{g}^{-1}$, recoveries $90-103 \%$ ), an additional sample preparation step of a preliminary extraction of analytes with water complicates the process. The analytes have high polarity and water solubility (Table 1) and could be easily extracted from soil. Nonetheless, Kenessov et al. (Kenessov et al. 2010b) showed that the addition of water to soil results in a decrease of the responses of analytes, which could 
be caused by higher affinity of analytes to water than soil. When analyzing water-containing samples by Vac-HSSPME, total pressure in the vial and extraction rates will be limited by the vapor pressure of water, particularly at higher extraction temperatures (Psillakis et al. 2013).

Recently, (Capetti et al. 2020), reported that storing the frankincense samples for $1 \mathrm{~h}$ at $-18^{\circ} \mathrm{C}$ before airevacuation overcame problems of volatiles (terpenes) losses due to aspiration. To exclude any discriminative losses from the headspace over time the authors also applied air-evacuation times of 45 and $120 \mathrm{~s}$ to the frozen samples and reported perfectly overlapping patterns for the most volatile compounds (being sampled at equilibrium) and a dramatic increase of the later eluting analytes (being sampled at pre-equilibrium) with Vac- and regular HSSPME. To further decrease losses of analytes, a higher amount of sample was taken for extraction. This approach uses standard vials and does not require any complex procedures during sample preparation.

The objective of this study was to develop the new method for accurate quantification UDMH TPs in sand samples based on Vac-HSSPME from 20-mL vials without addition of water. During the optimization step, effects of temperature and time during air-evacuation, incubation and extraction time, extraction temperature on the intensity and precision of analytes' responses were evaluated. The target UDMH TPS were: pyrazine (PAn), 1-methyl-1H-pyrazole (MPA), N-nitrosodimethylamine (NDMA), 1-methyl-1H1,2,4triazole (MTA) and $1 H$-pyrazole (PAI). NDMA and MTA were chosen as the main UDMH TPs, for which maximum permissible concentrations in soil are established in Kazakhstan -0.01 and $10 \mathrm{mg} \mathrm{kg}^{-1}$ (Ministry of National Economy of the Republic of Kazakhstan 2015), respectively. Other analytes represent most stable TPs, which can be used as markers of soil contamination with UDMH (Kenessov et al. 2012).

\section{Experimental}

\section{Reagents and materials}

The list of UDMH TPs, their origin and physicochemical properties are provided in Table 1. SPME was conducted using 85- $\mu \mathrm{m}$ Carboxen/polydimethylsiloxane (Car/PDMS, Supelco, Bellefonte, PA, USA), which provides highest extraction effectiveness of UDMH TPs (Grebel et al. 2006; Kenessov et al. 2010b).

In-house modified crimp-top Mininert ${ }^{\circledR}$ valves (Thomas Scientific) were built as described in (TrujilloRodríguez et al. 2017). A cylindrical Thermogreen ${ }^{\circledR}$ LB-1 septum with half-hole ( $6 \mathrm{~mm}$ diameter $\times 9 \mathrm{~mm}$ length, Supelco, USA) was placed into a 5-mm i.d. hole drilled in Mininert ${ }^{\circledR}$ valve to ensure leak-tight sealing of the valve. The optimized valve position in commercially available headspace vials was achieved by fitting O-rings having thickness $1-2 \mathrm{~mm}$.

\section{Model sand sample}

Sand sample was air-dried and sieved though a $6 \mathrm{~mm}$ mesh before analysis. The air-dried sample contained $86.8 \pm 0.9 \%$ of sand, $8.6 \pm 0.1 \%$ of dust, $4.6 \pm 0.1 \%$ of silt, $0.36 \pm 0.02 \%$ of water (ISO 2009 ), 
$1.81 \pm 0.09 \%$ of organic matter (ISO/CD), $34.0 \pm 0.5 \mathrm{mg} \mathrm{kg}^{-1}$ of nitrogen (ISO 1995), $61.0 \pm 0.5 \mathrm{mg} \mathrm{kg}^{-1} \mathrm{of}^{-}$ phosphorus (ISO 1994b), $370 \pm 6 \mathrm{mg} \mathrm{kg}^{-1}$ of potassium (GOST 1996). $\mathrm{pH}$ of the sample was $8.40 \pm 0.10$ (ISO 1994a). Concentrations of exchangeable $\mathrm{Ca}, \mathrm{Mg}$, Na and $\mathrm{K}$ were $5.3 \pm 0.2,2.93 \pm 0.15,0.041 \pm 0.004$ and $0.190 \pm 0.010 \mathrm{cmol} \mathrm{kg}^{-1}$ (ISO 2018), respectively.

\section{Vac-HSSPME procedure}

Vac-HSSPME optimization procedure for analyzing UDMH TPs in sand samples included five consequent steps: 1) spiking a weighted sand sample, 2) storing a sample at $-30^{\circ} \mathrm{C}$ or frozen by LN2 (extra freezing step for investigation), 3) air-evacuation of the vial, 4) Vac-HSSPME of analytes; 5) desorption in the GC inlet (Fig. 1). For regular HSSPME, the air evacuation step was omitted. The laboratory was not equipped with a special tonometer to measure the pressure inside the vial through the Mininert valve and for airevacuation, long air-evacuation time was chosen.

Prior to experiments, 20-mL crimp-top vials (HTA, Brescia, Italy) were washed with distilled water and preconditioned at $150^{\circ} \mathrm{C}$ for $2 \mathrm{~h}$ to remove possible interferences and contaminants. The air-died and sieved sand sample ( $m=1.00 \mathrm{~g}$ ) was introduced into $20-\mathrm{mL}$ vial and spiked with $10 \mu \mathrm{L}$ of UDMH TPs standard aqueous solution of pre-determined concentrations $0.67,1.74,2.45,5.80$ and $3.45 \mathrm{ng} \mathrm{hL}^{-1}$ for PAn, MPA, NDMA, MTA and Pal, respectively. Then, vials were crimped with aluminum caps and polytetrafluoroethylene (PTFE)/Silicone septa (Zhejiang Aijiren Technology Co, China), kept for $12 \mathrm{~h}$ at room temperature $\left(23^{\circ} \mathrm{C}\right)$ for equilibration and then located in a freezer $\left(T=-30^{\circ} \mathrm{C}\right)$ or frozen by liquid nitrogen (LN2) till the evacuation.

The vials with sand samples were air-evacuated using a low-cost single-stage rotary vane pump (Russia). For HSSPME under atmospheric pressure, air-evacuation step was omitted. Incubation of the samples was held in the agitator of MPS2 autosampler (Gerstel, Germany), and manual extraction was performed at desired extraction temperature and time. After extraction, the SPME fiber was introduced into the GC inlet for desorption of analytes.

\section{GC-MS conditions}

All analyses were conducted on a 7890A/5975C GC-MS (Agilent, USA) equipped with split/splitless and PTV (CIS4, Gerstel, Germany) inlets, and MPS2 (Gerstel, Germany) autosampler. UDMH TPs were desorbed from the Car/PDMS SPME fiber in a GC inlet in a splitless mode at $240^{\circ} \mathrm{C}$ using $0.75 \mathrm{~mm}$ i.d. liner (Supelco, USA). Separation of analytes was conducted using a polar $60 \mathrm{~m} \times 0.25 \mathrm{~mm}$ DB-WAXetr column (Agilent, USA) with a $0.5 \mu \mathrm{m}$ film thickness at a constant flow of a carrier gas $1.0 \mathrm{~mL} \mathrm{~min}{ }^{-1}$ (> $99.995 \%$, Orenburg-Techgas, Russia). The oven temperature was programmed from $80^{\circ} \mathrm{C}$ (held $5 \mathrm{~min}$ ) to

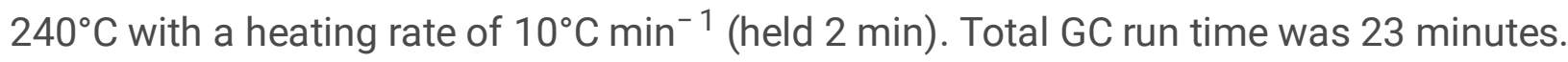

Temperatures of the MS interface, ion source and quadrupole were 240,230 , and $150^{\circ} \mathrm{C}$ respectively. MS detection was performed using the electron impact ionization at $70 \mathrm{eV}$ in the selection ion mode (SIM). The MS program used for the detection of the UDMH TPs in the SIM mode is provided in Table 2. 


\section{Study of the effects of temperature during air-evacuation step and incubation time}

HSSPME and Vac-HSSPME were compared at room temperature $\left(23^{\circ} \mathrm{C}\right)$. Three sample temperatures were tested during air-evacuation step for Vac-HSSPME: $23^{\circ} \mathrm{C},-30^{\circ} \mathrm{C}$ and frozen by LN2. Vac-HSSPME of spiked samples was conducted as described in Sect. 2.2 after air-evacuation for $120 \mathrm{~s}$. The samples were incubated for $30 \mathrm{~min}$ in the agitator of the autosampler at $40^{\circ} \mathrm{C}$ followed by 30 -min manual extraction at the same temperature. After extraction, the SPME fiber was introduced into the GC inlet for desorption of analytes. Three pre-incubation times (30,60 and $120 \mathrm{~min})$ were tested with extraction time and temperature for Vac-HSSPME set at $15 \mathrm{~min}$ and $40^{\circ} \mathrm{C}$, respectively.

\section{Study of the effects of extraction temperature and time}

The effect of extraction temperature was tested at $30,40,50$ and $60^{\circ} \mathrm{C}$. In this set of experiments, spiked sand samples were stored at freezing temperature $\left(-30^{\circ} \mathrm{C}\right)$ before air-evacuation for $120 \mathrm{~s}$. The incubation and extraction times were set at $30 \mathrm{~min}$.

Extraction profiles for each target analyte were obtained at $40^{\circ} \mathrm{C}$ using extraction times $5,15-, 30-, 60$ and 120 -min. Air-evacuation was conducted for $20 \mathrm{~s}$ at $23^{\circ} \mathrm{C}$, pre-incubation lasted for $30 \mathrm{~min}$ at $40^{\circ} \mathrm{C}$.

\section{Study of the effects of air-evacuation time and temperature}

Four air-evacuation times $(20,45,60,120 \mathrm{~s})$ and two air-evacuation temperatures $\left(23^{\circ} \mathrm{C}\right.$ and $\left.-30^{\circ} \mathrm{C}\right)$ were studied. After incubation for $30 \mathrm{~min}$, extraction for $30 \mathrm{~min}$ at $40^{\circ} \mathrm{C}$ was conducted.

\section{Analytical performance of the developed method}

Vac-HSSPME of sand samples was conducted for $30 \mathrm{~min}$ at $40^{\circ} \mathrm{C}$, evacuation time was $20 \mathrm{~s}$ at $23^{\circ} \mathrm{C}$, preincubation lasted for $30 \mathrm{~min}$ at $40^{\circ} \mathrm{C}$. For calibration, five standard samples were prepared by spiking 1.00 $\mathrm{g}$ of sand with $10.0 \mu \mathrm{L}$ of standard solutions of target analytes in water with concentrations $0.15-2.4$, 0.26-4.1, 0.70-11.2, 1.31-20.9 and 0.78-12.4 $\mathrm{ng} \mathrm{LL}^{-1}$ for Pan, MPA, NDMA, MTA and Pal, respectively. Calibration slopes and their standard deviations were determined using the method of least squares and LINEST function of MS Excel. Spike recoveries of UDMH TPs were determined by analyzing sand sample spiked $(10.0 \mu \mathrm{L})$ at the following concentrations of analytes: $15.1 \mathrm{ng} \mathrm{g}^{-1}$ for PAn, $25.5 \mathrm{ng} \mathrm{g}^{-1}$ for MPA, $69.8 \mathrm{ng} \mathrm{g}^{-1}$ for NDMA, $131 \mathrm{ng} \mathrm{g}^{-1}$ for MTA, $77.6 \mathrm{ng} \mathrm{g}^{-1}$ for PAI.

\section{Application of the developed method}

The developed method was applied for studying evaporation and transformation of UDMH TPs in model sand samples. Three model sand samples $(m=1.00 \mathrm{~g})$ were prepared in three replicates in nine 20-mL vials by spiking with 10.0 (Sample S1), 15.0 (Sample S2) and 20.0 (Sample S3) $\mu \mathrm{L}$ of the standard solution of target analytes in water with concentrations $1.81,1.97,5.96,11.1$ and $6.59 \mathrm{ng} \mathrm{\mu L}^{-1}$ for Pan, MPA, NDMA, MTA and Pal, respectively (Table S1). Then, samples in open vials were kept at room 
temperature $\left(23^{\circ} \mathrm{C}\right)$ in the hood for $3 \mathrm{~d}$ and then located in the freezer $\left(-18^{\circ} \mathrm{C}\right)$ for $5 \mathrm{~d}$ before analyzing using the developed method at optimized parameters.

\section{Results And Discussion}

\section{Effect of temperature during air-evacuation step}

Responses of MTA and PAl obtained by Vac-HSSPME at $23^{\circ} \mathrm{C}$ were 2.1-2.3 times higher than those obtained by HSSPME while responses of Pan, MPA, and NDMA were lower by 32-76\% (Fig. 2). Lower responses of Pan, MPA and NDMA after Vac-HSSPME could be caused by the losses of analytes during the air-evacuation step. Molecules of analytes are present in the headspace and can be removed from a vial together with air. To avoid such losses, freezing a sample before air-evacuation step was used as proposed by (Capetti et al. 2020).

Freezing samples before air-evacuation yielded 1.3-3.4 times higher responses of analytes (Fig. 2). These results prove that the decrease of temperature during air-evacuation allows decreasing losses of analytes. Vac-HSSPME after air-evacuation at $-30^{\circ} \mathrm{C}$ provided $1.3-4.8$-fold higher responses of NDMA, MTA and PAI compared to HSSPME. The effect of low pressure on Pan and MPA was negligible, probably, because of their higher headspace-soil distribution constants and solid-phase resistance (Psillakis et al. 2012a).

Further decrease in air-evacuation temperature by applying LN2 did not result in a substantial increase in responses of analytes (Fig. S1 in SM). Therefore, freezing of samples at $-30^{\circ} \mathrm{C}$ was selected as optimal for the air-evacuation step and used in the following experiments.

\section{Effect of pre-incubation time}

Pre-incubation of a sample at extraction temperature is required prior to extraction for its equilibration with headspace and ensuring a reproducibility (Risticevic et al. 2010). A proper pre-incubation of a frozen sample is particularly important due to longer time of water melting and sample heating to the extraction temperature. For all UDMH TPs, responses dramatically decreased when increasing the pre-incubation time up to $30 \mathrm{~min}$ (Fig. S2 in SM). The highest responses of all analytes were observed at pre-incubation

time 30 min. At shorter pre-incubation times, remarkably high RSDs were observed reaching $30 \%$ after 10 min pre-incubation, which can be caused by a very slow melting of frozen samples. The best combination of responses of analytes and their RSDs ( $£ 7 \%$ ) was achieved at pre-incubation time $30 \mathrm{~min}$, which was chosen as optimal for further experiments.

\section{Effect of extraction temperature on analytes response}

Responses of all analytes increased by $27-80 \%$ when extraction temperature increased from 30 to $40{ }^{\circ} \mathrm{C}$ (Fig. 3). Further heating of sand samples to $50{ }^{\circ} \mathrm{C}$ led to decreased extraction effectiveness of PAn, MPA and NDMA by $26-36 \%$, whereas responses of MTA and PAl increased by $43-60 \%$ and reached their maxima. Heating samples from $50{ }^{\circ} \mathrm{C}$ to $60^{\circ} \mathrm{C}$ yielded a decrease in responses of all analytes by $10-28 \%$. 
RSDs at all studied extraction temperatures varied from 2.0 to $22 \%$. The local maxima of extraction temperature profiles can be due to the reduction of the fiber-headspace distribution constant due to the increase of extraction temperature (Schulten and Schnitzer 1997; Kenessov et al. 2010b). An extraction temperature of $40{ }^{\circ} \mathrm{C}$ was chosen as optimal, for which RSDs were below $22 \%$.

\section{Effect of the duration of the air-evacuation step at different sample temperatures}

Evacuating samples for $120 \mathrm{~s}$ at room temperature resulted in substantial losses of analytes. It was therefore decided to investigate the effect of air-evacuation time on analyte losses as a function of sample temperature i.e. at room temperature and $-30^{\circ} \mathrm{C}$. Four air-evacuation times, ranging from 20 to $120 \mathrm{~s}$ were tested for each temperature (Fig. 4). At room temperature, reducing the evacuation time from 120 to 20 s resulted in a $25-46 \%$ increase in responses. At the same time, decreasing the air-evacuation time of frozen samples yielded similar responses considering the variability range (RSDs) $1.0-15 \%$ (Fig. 4, b). Paired sample $t$-test confirmed that there was no significant difference between analytes' responses obtained by Vac-HSSPME at air-evacuation times of 20 and $120 \mathrm{~s}$ at $-30^{\circ} \mathrm{C}(\mathrm{P}>0.05$ for four analytes). Moreover, the results for $20 \mathrm{~s}$ of evacuation were the same for the two sample temperatures tested (Fig. 5).

Freezing the samples is an effective approach to minimize losses of analytes during air-evacuation in the presence of the sample. The results presented here confirmed that air-evacuation time must always be kept minimum as depending on the sample type, this may eliminate the extra step of freezing samples. In any case, when removing the air in the presence of the sample, the effects of air-evacuation time and the sample temperature must be evaluated and optimized. Based on the above results and discussion, it was decided to air-evacuate the samples at room temperature for $20 \mathrm{~s}$.

\section{Effect of extraction time}

For all studied UDMH TPs, responses increased when increasing the extraction time from 5 to 30 min (Figure 6). A plateau of PAn, MPA and NDMA responses was reached at extraction time 30 min. Further increase in extraction time ( $>30 \mathrm{~min}$ ) resulted in a minor increase in responses of PAn, MPA and NDMA (by 6-10\%). Responses of MTA and PAl continued increasing even after 120 min of extraction.

RSD s of UDMH TPs responses for all studied extraction times varied from 1.0 to $21 \%$. Maximum value of RSDs (21\%) was obtained at extraction time 5 min. Lowest RSDs (£14\%) were observed after 30 and 120 min of extraction.

Based on the obtained results, extraction time 30 min was chosen as optimal as it apparently provides best combination of precision and sensitivity for determination of UDMH TPs in sand samples using VacHSSPME. Longer extraction time may cause an increase in errors due to the saturation of SPME fiber coating and enhanced competition with matrix compounds (Risticevic et al. 2010). 


\section{Analytical performance of the developed method}

Calibration plots with determination coefficients $\left(R^{2}\right)$ in the range from 0.9912 to 0.9938 in studied concentration ranges were obtained (Table 3). RSDs of the slopes of obtained calibration plots were 3.9$4.7 \%$ for all studied analytes. The developed method provided low detection limits (LODs) ranging from 0.035 to $3.6 \mathrm{ng} \mathrm{g}^{-1}$.

Spike recoveries of target analytes from sand samples were $84-97 \%$ with RSDs $1.0-11 \%$ (Table 4), which proves the accuracy of the developed method.

Application of the developed method

The developed method was applied for studying evaporation and transformation of UDMH TPs in model sand samples. Determined concentrations of analytes in sand samples after $3 \mathrm{~d}$ of storage in open vials showed substantial losses varying from 41 to $94 \%$ (Table 5). As most of these compounds show good chemical stability, the losses were mostly caused by their evaporation. Such a quick evaporation can be caused by the low moisture content and surface area of sand, and its low affinity to analytes. RSDs of three replicates of the samples did not exceed $14 \%$. For Pan, MPA, NDMA and MTA, highest relative losses (\%) were observed at highest initial concentrations. For Pal, there was no trend. Among analytes, highest losses (90.2-94.3\%) were observed for Pan. Lowest losses (41-42\%) were for MPA at initial concentrations 20 and $30 \mathrm{ng} \mathrm{g}^{-1}$, while initial concentration of MPA $39 \mathrm{ng} \mathrm{g}^{-1}$ yielded a $69 \pm 4 \%$ reduction. Initial concentrations of NDMA 60 and $89 \mathrm{ng} \mathrm{g}^{-1}$ resulted in $76 \pm 4$ and $73.3 \pm 1.7 \%$ decrease, respectively, whereas the concentration $119 \mathrm{ng} \mathrm{g}^{-1}$ showed an $85.4 \pm 1.8 \%$ reduction.

\section{Comparison of the developed method to other methods based on HSSPME}

Compared to existing methods based on HSSPME, the developed method provides lower detection limits (Table 6), better precision and accuracy due to the absence of oxygen during extraction. Its main advantage over the only existing method based on Vac-HSSPME is a simpler sample preparation because a preliminary extraction by water is not required. In addition, it results in a better precision and accuracy at 2.5-8 times lower LODs.

\section{Conclusion}

Thus, the new method has been developed for simultaneous quantification of major transformation products of toxic rocket fuel unsymmetrical dimethylhydrazine in sand using vacuum-assisted headspace solid-phase microextraction. Extraction under vacuum at $30^{\circ} \mathrm{C}$ allowed achieving 1.3-4.8-fold higher responses of NDMA, MTA and PAl compared to regular HSSPME. Air-evacuating the sample for $120 \mathrm{~s}$ at room temperature resulted in major losses of analytes. Decreasing the air-evacuation time from 120 to $20 \mathrm{~s}$ at room temperature allowed $25-46 \%$ fold increase in responses of analytes obtained by VacHSSPME. At $-30^{\circ} \mathrm{C}$, no significant change in responses of analytes was observed at varying air evacuation times. The best combination of responses and their RSDs was achieved after air-evacuation 
of a sample ( $m=1.0 \mathrm{~g}$ ) for $20 \mathrm{~s}$ at room temperature, incubation for $30 \mathrm{~min}$ and extraction for $30 \mathrm{~min}$ at $40^{\circ} \mathrm{C}$. The developed method provided linear calibration plots with coefficients of determination ranging from 0.9912 to 0.9938 in studied ranges of concentrations. LODs varied from 0.035 to $3.6 \mathrm{ng} \mathrm{g}^{-1}$.

It has been proven that freezing the samples is an effective approach to minimize analyte losses during air-evacuation in the presence of the solid sample. The results presented here confirmed that airevacuation time must always be kept to a minimum as depending on the sample type this may eliminate the extra step of freezing samples. In any case, when removing the air in the presence of the sample the effects of air evacuation time and the sample temperature must be evaluated and optimized.

The developed method has several important advantages over existing methods including lower detection limits, better accuracy and precision. Its major advantage over other existing methods based on HSSPME is the extraction at the substantially decreased concentration of oxygen, which should minimize oxidation processes and changes in concentrations of analytes. It can be further expanded to a greater number of analytes and soil types.

The method can be recommended for application in environmental analytical laboratories dealing with analysis of soil contaminated with rocket fuel. It could be used for research experiments on transformation and evaporation of UDMH transformation products where their concentrations can reach $\mathrm{ppb}$ levels. The method can also be useful for studying the horizontal and vertical migration of UDMH TPs in sand and a more accurate mapping of the contamination of fall places of carrier rockets and their burned-out stages.

\section{Declarations}

Ethics approval and consent to participate Not applicable.

Consent for publication Not applicable.

Availability of data and materials All data generated or analysed during this study are included in this published article (and its supplementary information files). Besides, the datasets used and/or analyzed during the current study are available from the corresponding author on reasonable request.

Competing interests The authors declare that they have no competing interests.

\section{Funding}

This research was funded by the Ministry of Education and Science of the Republic of Kazakhstan (Grant No. AP05133158 and Ph.D. scholarship of AZ). The authors would like to thank Al-Farabi Kazakh National University for the postdoctoral scholarship of NB. This article is based upon work from the Sample Preparation Task Force and Network, supported by the Division of Analytical Chemistry of the European Chemical Society. 
Aray Zhakupbekova: Methodology, Validation, Formal analysis, Investigation, Writing - original draft, Writing - Review \& Editing, Visualization. Nassiba Baimatova: Conceptualization, Methodology, Writing original draft, Writing - Review \& Editing, Project administration. Elefteria Psillakis: Conceptualization, Writing - Review \& Editing. Bulat Kenessov: Conceptualization, Writing - Review \& Editing, Supervision, Funding acquisition.

\section{Acknowledgements}

Authors would like to thank PhD students of Al-Farabi Kazakh National University Olga Ibragimova and Bauyrzhan Bukenov for technical support.

\section{References}

1. Bakaikina NV, Kenessov B, Ul'yanovskii NV et al (2017) Quantification of transformation products of unsymmetrical dimethylhydrazine in water using SPME and GC-MS. Chromatographia 80:931-940. https://doi.org/10.1007/s10337-017-3286-2

2. Bakaikina NV, Kenessov B, Ul'yanovskii NV, Kosyakov DS (2018) Quantification of transformation products of rocket fuel unsymmetrical dimethylhydrazine in soils using SPME and GC-MS. Talanta 184:332-337. https://doi.org/10.1016/j.talanta.2018.02.047

3. Beiranvand M, Ghiasvand A (2017) Simple, low-cost and reliable device for vacuum-assisted headspace solid-phase microextraction of volatile and semivolatile compounds from complex solid Samples. Chromatographia 80:1771-1780. https://doi.org/10.1007/s10337-017-3422-z

4. Brunton NP, Cronin DA, Monahan FJ (2001) The effects of temperature and pressure on the performance of Carboxen/PDMS fibres during solid phase microextraction (SPME) of headspace volatiles from cooked and raw turkey breast. Flav Frag J 16:294-302. https://doi.org/10.1002/ffj.1000

5. Buryak AK, Tataurova O, Ulyanov A (2004) Study of transformation products of unsymmetrical dimethylhydrazine on model sorbents by the method of gas chromatography/mass spectrometry. Russ J Mass Spectrom 1:147. https://doi.org/(In Russian)

6. Capetti F, Rubiolo P, Bicchi C et al (2020) Exploiting the versatility of vacuum-assisted headspace solid-phase microextraction in combination with the selectivity of ionic liquid-based GC stationary phases to discriminate Boswellia spp. resins through their volatile and semivolatile fractions. J Sep Sci 43:1-11. https://doi.org/10.1002/jssc.202000084

7. Carlsen L, Kenesova OA, Batyrbekova SE (2007) A preliminary assessment of the potential environmental and human health impact of unsymmetrical dimethylhydrazine as a result of space activities. Chemosphere 67:1108-1116. https://doi.org/10.1016/j.chemosphere.2006.11.046

8. Carlsen L, Kenessov BN, Batyrbekova SY et al (2009) Assessment of the mutagenic effect of 1,1dimethyl hydrazine. Environ Toxicol Pharmacol 28:448-452. 
https://doi.org/10.1016/j.etap.2009.08.004

9. Carlsen L, Kenessov BN, Batyrbekova SY (2008) A QSAR/QSTR Study on the Environmental Health Impact by the Rocket Fuel 1,1-Dimethyl Hydrazine and its Transformation Products. Environ Health Insights 1:11-20. https://doi.org/10.1016/j.etap.2009.01.005

10. Ghiasvand A, Koonani S, Yazdankhah F, Farhadi S (2018a) A comparison study on a sulfonated graphene-polyaniline nanocomposite coated fiber for analysis of nicotine in solid samples through the traditional and vacuum-assisted HS-SPME. J Pharm Biomed Anal 149:271-277. https://doi.org/10.1016/j.jpba.2017.11.020

11. Ghiasvand A, Zarghami F, Beiranvand M (2018b) Ultrasensitive direct determination of BTEX in polluted soils using a simple and novel pressure-controlled solid-phase microextraction setup. J Iran Chem Soc 15:1051-1059. https://doi.org/10.1007/s13738-018-1302-6

12. GOST (1996) GOST 26205-91. Soils. Determination of mobile compounds of phosphorus and potassium by Machigin method modified by CINAO

13. Grebel JE, Young CC, Suffet IH (Mel (2006) Solid-phase microextraction of N-nitrosamines. J Chromatogr A 1117:11-18. https://doi.org/10.1016/j.chroma.2006.03.044

14. Gunter's Space Page (2019) Orbital Launches of 2018. In: Gunter's Sp. Page. https://space.skyrocket.de/doc_chr/lau2018.htm

15. ISO/CD ISO/CD 23265. Soil quality. Test for estimating organic matter decomposition in contaminated soil

16. ISO (2009) ISO 11277:2009. Soil quality. Determination of particle size distribution in mineral soil material. Method by sieving and sedimentation

17. ISO (1994a) ISO 10390:1994. Soil quality. Determination of pH

18. ISO (1995) ISO 11261:1995. Soil quality. Determination of total nitrogen. Modified Kjeldahl method

19. ISO (1994b) ISO 11263:1994. Soil quality. Determination of phosphorus. Spectrometric determination of phosphorus soluble in sodium hydrogen carbonate solution

20. ISO (2018) ISO 23470:2018. Soil quality. Determination of effective cation exchange capacity (CEC) and exchangeable cations using a hexamminecobalt (III) chloride solution

21. Kenessov B, Alimzhanova M, Sailaukhanuly $Y$ et al (2012) Transformation products of 1,1dimethylhydrazine and their distribution in soils of fall places of rocket carriers in Central Kazakhstan. Sci Total Environ 427-428:78-85. https://doi.org/https://doi.org/10.1016/j.scitotenv.2012.04.017

22. Kenessov B, Koziel JA, Bakaikina NV, Orazbayeva D (2016) Perspectives and challenges of on-site quantification of organic pollutants in soils using solid-phase microextraction. Trends Anal Chem 85:111-122. https://doi.org/10.1016/j.trac.2016.04.007

23. Kenessov B, Sailaukhanuly Y, Koziel JA et al (2011) GC-MS and GC-NPD determination of formaldehyde dimethylhydrazone in water using SPME. Chromatographia 73:123-128. https://doi.org/10.1007/s10337-010-1820-6 
24. Kenessov BN, Koziel JA, Grotenhuis T, Carlsen L (2010a) Screening of transformation products in soils contaminated with unsymmetrical dimethylhydrazine using headspace SPME and GC-MS. Anal Chim Acta 674:32-39. https://doi.org/10.1016/j.aca.2010.05.040

25. Kenessov BN, Koziel JA, Grotenhuis T, Carlsen L (2010b) Screening of transformation products in soils contaminated with unsymmetrical dimethylhydrazine using headspace SPME and GC-MS. Anal Chim Acta 674:32-39. https://doi.org/10.1016/j.aca.2010.05.040

26. Kolesnikov S (2014) Oxidation of unsymmetric dimethylhydrazine (heptyl) and identification of its transformation products during spills. SibAK, Novosibirsk

27. Kosyakov DS, Ul'yanovskii NV, Bogolitsyn KG, Shpigun OA (2014) Simultaneous determination of 1,1dimethylhydrazine and products of its oxidative transformations by liquid chromatography-tandem mass spectrometry. Int J Environ Anal Chem 94:1254-1263. https://doi.org/10.1080/03067319.2014.940342

28. Kosyakov DS, Ul'yanovskii NV, Pokryshkin SA et al (2015) Rapid determination of 1,1dimethylhydrazine transformation products in soil by accelerated solvent extraction coupled with gas chromatography-tandem mass spectrometry. Int J Environ Anal Chem 95:1321-1337. https://doi.org/10.1080/03067319.2015.1090569

29. Llompart M, Celeiro M, García-Jares C, Dagnac T (2019) Environmental applications of solid-phase microextraction. Trends Anal Chem 112:1-12. https://doi.org/10.1016/j.trac.2018.12.020

30. Llompart M, Li K, Fingas M (1999) Headspace solid phase microextraction (HSSPME) for the determination of volatile and semivolatile pollutants in soils. Talanta 48:451-459

31. Ministry of National Economy of the Republic of Kazakhstan (2015) Annex 3 to the order No. 168 of the Minister of National Economy of the Republic of Kazakhstan (2015) "On the approval of hygienic standards for atmospheric air in urban and rural settlements" from 28.02.2015, Astana, Kazakhstan (In Russian)

32. NIOSH (1997) The National Institute for Occupational Safety and Health. Registry of Toxic Effects of Chemical Substances. In: U.S. Dep. Heal. Hum. Serv. https://www.cdc.gov/niosh/docs/97119/default.html

33. NIOSH (2018) The National Institute for Occupational Safety and Health. Hydrazine, 1,1-dimethyl-. In: U.S. Dep. Heal. Hum. Serv. https://www.cdc.gov/niosh-rtecs/MV256250.html

34. Orazbayeva D, Kenessov B, Psillakis E et al (2018a) Determination of transformation products of unsymmetrical dimethylhydrazine in water using vacuum-assisted headspace solid-phase microextraction. J Chromatogr A 1555:30-36. https://doi.org/10.1016/j.chroma.2018.04.048

35. Orazbayeva D, Kenessov B, Zhakupbekova A (2018b) Quantification of transformation products of unsymmetrical dimethylhydrazine in aqueous extracts from soil based on vacuum-assisted headspace solid-phase microextraction. Chem Bull Kazakh Natl Univ 4-11. https://doi.org/10.15328/cb1014

36. Psillakis E (2017) Vacuum-assisted headspace solid-phase microextraction: A tutorial review. Anal Chim Acta 986:12-24. https://doi.org/10.1016/j.aca.2017.06.033 
37. Psillakis E, Mousouraki A, Yiantzi E, Kalogerakis N (2012a) Effect of Henry's law constant and operating parameters on vacuum-assisted headspace solid phase microextraction. $J$ Chromatogr $A$ 1244:55-60. https://doi.org/10.1016/j.chroma.2012.05.006

38. Psillakis E, Yiantzi E, Kalogerakis N (2013) Downsizing vacuum-assisted headspace solid phase microextraction. J Chromatogr A 1300:119-126. https://doi.org/10.1016/j.chroma.2013.02.009

39. Psillakis E, Yiantzi E, Sanchez-Prado L, Kalogerakis N (2012b) Vacuum-assisted headspace solid phase microextraction: Improved extraction of semivolatiles by non-equilibrium headspace sampling under reduced pressure conditions. Anal Chim Acta. https://doi.org/10.1016/j.aca.2012.01.019

40. Risticevic S, Lord H, Górecki T et al (2010) Protocol for solid-phase microextraction method development. Nat Protoc 1:122-139. https://doi.org/10.1038/nprot.2009.179

41. Rodin IA, Anan'eva IA, Smolenkov AD, Shpigun OA (2010) Determination of the products of the oxidative transformation of unsymmetrical dimethylhydrazine in soils by liquid chromatography/mass spectrometry. J Anal Chem 65:1405-1410. https://doi.org/10.1134/S1061934810130150

42. Rodin IA, Moskvin DN, Smolenkov AD, Shpigun OA (2008) Transformations of asymmetric dimethylhydrazine in soils. Russ J Phys Chem A 82:911-915. https://doi.org/10.1134/S003602440806006X

43. Rodin IA, Smirnov RS, Smolenkov AD et al (2012) Transformation of unsymmetrical dimethylhydrazine in soils. Eurasian Soil Sci 45:386-391. https://doi.org/10.1134/S1064229312040096

44. Schulten HR, Schnitzer M (1997) The chemistry of soil organic nitrogen: A review. Biol Fertil Soils 26:1-15. https://doi.org/10.1007/s003740050335

45. Trujillo-Rodríguez MJ, Pino V, Psillakis E et al (2017) Vacuum-assisted headspace-solid phase microextraction for determining volatile free fatty acids and phenols. Investigations on the effect of pressure on competitive adsorption phenomena in a multicomponent system. Anal Chim Acta 962:41-51. https://doi.org/10.1016/j.aca.2017.01.056

46. U.S. EPA (1984) United States Environmental Protection Agency. Health And Environmental Effects Profile for 1,1-Dimethylhydrazine. In: Washington, D.C. EPA/600/X-84/134 (NTIS PB88130083)

47. Ul'yanovskii NV, Kosyakov DS, Pikovskoi II, Khabarov YG (2017) Characterisation of oxidation products of 1,1-dimethylhydrazine by high-resolution orbitrap mass spectrometry. Chemosphere 174:66-75. https://doi.org/10.1016/j.chemosphere.2017.01.118

48. Ul'yanovskii NV, Kosyakov DS, Pokryshkin SA, Bogolitsyn KG (2015) Determination of transformation products of 1,1-dimethylhydrazine by gas chromatography-tandem mass spectrometry. J Anal Chem 70:1553-1560. https://doi.org/10.1134/S1061934815130080

49. Yegemova S, Bakaikina NV, Kenessov B et al (2015) Determination of 1-methyl-1H-1,2,4-triazole in soils contaminated by rocket fuel using solid-phase microextraction, isotope dilution and gas chromatography-mass spectrometry. Talanta 143:226-233. https://doi.org/10.1016/j.talanta.2015.05.045 
50. Yiantzi E, Kalogerakis N, Psillakis E (2015) Vacuum-assisted headspace solid phase microextraction of polycyclic aromatic hydrocarbons in solid samples. Anal Chim Acta 890:108-116. https://doi.org/10.1016/j.aca.2015.05.047

51. Yiantzi E, Kalogerakis N, Psillakis E (2016) Design and testing of a new sampler for simplified vacuum-assisted headspace solid-phase microextraction. Anal Chim Acta 927:46-54. https://doi.org/10.1016/j.aca.2016.05.001

52. Zhakupbekova A, Baimatova N, Kenessov B (2019) A critical review of vacuum-assisted headspace solid-phase microextraction for environmental analysis. Trends Environ Anal Chem 22:65. https://doi.org/10.1016/j.teac.2019.e00065

53. Zhubatov ZK, Kenessov B, Bakaikina NV et al (2016) Fast Determination of 1-Methyl-1H-1,2,4-triazole in Soils Contaminated by Rocket Fuel Using Solvent Extraction, Isotope Dilution and GC-MS. Chromatographia 79:491-499. https://doi.org/10.1007/s10337-016-3054-8

\section{Tables}

\section{Table 1}

Physicochemical properties of analytes.

\begin{tabular}{|c|c|c|c|c|c|}
\hline \multicolumn{2}{|c|}{ Analytes } & Molecular weight (Da) & $K_{H}\left(\right.$ atm m ${ }^{3}$ mole $\left.^{-1}\right)$ & $\log K_{o w}$ & Boiling point $\left({ }^{\circ} \mathrm{C}\right)$ \\
\hline MPA ( $\geq 98.0 \%)$ & & 82.1 & $7.88 \cdot 10^{-5}$ & 0.23 & 127 \\
\hline Pal ( $\geq 99.0 \%)$ & & 68.1 & $3.69 \cdot 10^{-6}$ & 0.26 & 187 \\
\hline NDMA ( $\geq 99.5 \%)$ & Supelco, USA & 74.1 & $1.82 \cdot 10^{-6}$ & -0.57 & 154 \\
\hline
\end{tabular}

\section{Table 2}

MS detection program for UDMH TPs in SIM mode.

\begin{tabular}{lccccc}
\hline Analyte & $\begin{array}{c}\text { Retention } \\
\text { time } \\
(\text { min })\end{array}$ & $\begin{array}{c}\text { CAS } \\
\text { Number }\end{array}$ & $\begin{array}{c}\text { Quantification ions }\left(m z^{-1},\right. \\
(\text { dwell }))\end{array}$ & $\begin{array}{c}\text { Confirmation ion }(m \\
\left.z^{-1}\right)\end{array}$ & $\begin{array}{c}\text { Group start time } \\
(\text { min })\end{array}$ \\
\hline PAn & 10.9 & $290-37-9$ & $80(100)$ & 53 & 10.0 \\
\hline MPA & 11.5 & $930-36-9$ & $82(100)$ & 81 & 13.0 \\
\hline NDMA & 12.8 & $62-75-9$ & $74(100)$ & 42 & 16.0 \\
\hline MTA & 16.9 & $6086-21-1$ & $83(100)$ & 56 & 18.6 \\
\hline PAl & 19.5 & $288-13-1$ & $68(100)$ & 41 & \\
\hline
\end{tabular}

\section{Table 3}

Analytical performance of the developed method. 


\begin{tabular}{lccccc}
\hline Compound & Concentration range $\left(\mathrm{ng} \mathrm{g}^{-1}\right)$ & $R^{2}$ & RSDs of slope (\%) & LOD $\left(\mathrm{ng} \mathrm{g}^{-1}\right)$ & LOQ $\left(\mathrm{ng} \mathrm{g}^{-1}\right)$ \\
\hline PAn & $1.5-24$ & 0.9919 & 4.5 & 0.035 & 0.12 \\
\hline MPA & $2.6-41$ & 0.9912 & 4.7 & 0.17 & 0.56 \\
\hline NDMA & $7.0-112$ & 0.9913 & 4.7 & 0.22 & 0.73 \\
\hline MTA & $13-209$ & 0.9938 & 3.9 & 3.6 & 12 \\
\hline PAl & $7.8-124$ & 0.9930 & 4.2 & 0.35 & 1.2 \\
\hline
\end{tabular}

Note: The LODs and LOQs were calculated as 3:1 and 10:1 signal-to-noise (S/N) ratios, respectively. S/N ratios were calculated from chromatograms of sand samples with lowest concentration of each analyte

\section{Table 4}

Recoveries of target analytes from spiked sand samples obtained using the developed method based on VacHSSPME.

\begin{tabular}{lccc}
\hline Analytes & Spiked $\left(\mathrm{ng} \mathrm{g}^{-1}\right)$ & Determined $\left(\mathrm{ng} \mathrm{g}^{-1}\right)$ & Recovery (\%) \\
\hline PAn & 15.1 & $12.7 \pm 0.5$ & $84 \pm 4$ \\
\hline MPA & 25.5 & $23 \pm 2$ & $89 \pm 11$ \\
\hline NDMA & 69.8 & $63 \pm 4$ & $91 \pm 7$ \\
\hline MTA & 131 & $122.5 \pm 1.3$ & $93.7 \pm 1.0$ \\
\hline PAl & 77.6 & $75 \pm 8$ & $97 \pm 10$ \\
\hline
\end{tabular}

\section{Table 5}

Concentrations of analytes in model sand samples after keeping them in open 20-mL vials for $3 \mathrm{~d}$ determined using the developed method.

\begin{tabular}{|c|c|c|c|c|c|c|c|c|c|}
\hline \multirow[t]{2}{*}{ Compound } & \multicolumn{3}{|c|}{ Spiked concentration $\left(\mathrm{ng} \mathrm{g}^{-1}\right)$} & \multicolumn{3}{|c|}{ Measured concentration $\left(\mathrm{ng} \mathrm{g}^{-1}\right)$} & \multicolumn{3}{|c|}{ Losses (\%) } \\
\hline & $\mathrm{S} 1$ & $\mathrm{~S} 2$ & S3 & $\mathrm{S} 1$ & $\mathrm{~S} 2$ & S3 & $\mathrm{S} 1$ & $\mathrm{~S} 2$ & S3 \\
\hline PAn & 18 & 27 & 36 & $1.70 \pm 0.15$ & $2.65 \pm 0.13$ & $2.1 \pm 0.2$ & $90.6 \pm 0.8$ & $90.2 \pm 0.5$ & $94.3 \pm 0.6$ \\
\hline MPA & 20 & 30 & 39 & $11.3 \pm 1.2$ & $17.6 \pm 1.6$ & $12.1 \pm 1.5$ & $42 \pm 6$ & $41 \pm 5$ & $69 \pm 4$ \\
\hline NDMA & 60 & 89 & 119 & $15 \pm 2$ & $23.8 \pm 1.5$ & $17.0 \pm 2.2$ & $76 \pm 3$ & $73.3 \pm 1.7$ & $85.4 \pm 1.8$ \\
\hline MTA & 111 & 167 & 222 & $21 \pm 2$ & $33.0 \pm 0.6$ & $28.2 \pm 1.9$ & $81 \pm 2$ & $80.2 \pm 0.4$ & $87.3 \pm 0.8$ \\
\hline $\mathrm{PAl}$ & 66 & 99 & 132 & $12.28 \pm 0.07$ & $23.6 \pm 0.5$ & $26 \pm 3$ & $81.36 \pm 0.10$ & $76.1 \pm 0.5$ & $81 \pm 2$ \\
\hline
\end{tabular}

\section{Table 6}

Methods for determination of UDMH TPs in soil samples based on HSSPME. 


\begin{tabular}{|c|c|c|c|c|c|c|c|c|c|}
\hline \multirow[t]{2}{*}{ Analytes } & \multirow{2}{*}{$\begin{array}{l}\text { Sample } \\
\text { amount } \\
\text { (g) }\end{array}$} & \multirow{2}{*}{$\begin{array}{l}\text { Volume of } \\
\text { extraction } \\
\text { solvent } \\
(\mathrm{mL})\end{array}$} & \multirow{2}{*}{$\begin{array}{c}\text { Sample } \\
\text { preparation }\end{array}$} & \multirow[t]{2}{*}{$\begin{array}{l}\text { Optimized } \\
\text { parameters }\end{array}$} & \multirow{2}{*}{$\begin{array}{l}\text { Quantification } \\
\text { approach }\end{array}$} & \multirow{2}{*}{$\begin{array}{l}\text { Detection } \\
\quad \text { limit } \\
\left(\mathrm{ng} \mathrm{g}^{-1}\right)\end{array}$} & \multicolumn{2}{|c|}{$\begin{array}{c}\text { Analytical } \\
\text { parameters }\end{array}$} & \multirow[t]{2}{*}{ Ref } \\
\hline & & & & & & & $R^{2}$ & $\begin{array}{c}\mathrm{RSD} \\
(\%)\end{array}$ & \\
\hline $\begin{array}{l}21 \\
\text { UDMH } \\
\text { TPs }\end{array}$ & 1 & 5 & $\begin{array}{l}\text { HSSPME } \\
\text { from } \\
\text { aqueous } \\
\text { extracts }\end{array}$ & $\begin{array}{c}85-\mu \mathrm{m} \text { Car/PDMS at } \\
40{ }^{\circ} \mathrm{C} \text { for } 60 \mathrm{~min}, \\
1.5 \mathrm{~g} \mathrm{NaCl}\end{array}$ & Screening & - & - & - & $\begin{array}{l}\text { (Kenessov } \\
\text { et al. } \\
\text { 2010b) }\end{array}$ \\
\hline MTA & 1 & - & HSSPME & $\begin{array}{c}\text { 85- } \mu \mathrm{m} \text { Car/PDMS at } \\
80^{\circ} \mathrm{C} \text { for } 1 \mathrm{~min}\end{array}$ & $\begin{array}{l}\text { Isotopic } \\
\text { dilution }\end{array}$ & 1000 & $\mathrm{n} / \mathrm{p}$ & $<17$ & $\begin{array}{l}\text { (Yegemova } \\
\text { et al. 2015) }\end{array}$ \\
\hline $\begin{array}{l}19 \\
\text { UDMH } \\
\text { TPs }\end{array}$ & 1 & - & HSSPME & $\begin{array}{l}\text { Pre-incubation for } 5 \\
\text { min, } 85-\mu \mathrm{m} \\
\text { Car/PDMS at } 40{ }^{\circ} \mathrm{C} \\
\text { for } 60 \mathrm{~min} \\
\end{array}$ & $\begin{array}{c}\text { Standard } \\
\text { addition }+ \\
\text { internal } \\
\text { standard }\end{array}$ & $1.0-14$ & $\begin{array}{l}0.9352- \\
0.9921\end{array}$ & $<22$ & $\begin{array}{c}\text { (Bakaikina } \\
\text { et al. 2018) }\end{array}$ \\
\hline $\begin{array}{l}\text { Pan } \\
\text { MPA } \\
\text { NDMA } \\
\text { MTA } \\
\text { MIA PAl }\end{array}$ & 2 & 7 & $\begin{array}{l}\text { Vac- } \\
\text { HSSPME } \\
\text { from } \\
\text { aqueous } \\
\text { extracts }\end{array}$ & $\begin{array}{c}\text { Incubation for } 10 \\
\text { min, evacuation for } \\
120 \mathrm{~s}, 85-\mu \mathrm{m} \\
\text { Car/PDMS at } 50{ }^{\circ} \mathrm{C} \\
\text { and } 1500 \mathrm{rpm} \text { for } 30 \\
\text { min, } 35 \% \mathrm{NaCl}\end{array}$ & $\begin{array}{l}\text { Standard } \\
\text { addition }\end{array}$ & $0.2-9$ & $\begin{array}{l}0.991- \\
0.998\end{array}$ & $\begin{array}{l}0.9- \\
7.7\end{array}$ & $\begin{array}{c}\text { (Orazbayeva } \\
\text { et al. } \\
\text { 2018b) }\end{array}$ \\
\hline $\begin{array}{l}\text { Pan } \\
\text { MPA } \\
\text { NDMA } \\
\text { MTA PAl }\end{array}$ & 1 & - & $\begin{array}{c}\text { Vac- } \\
\text { HSSPME }\end{array}$ & $\begin{array}{l}\text { Pre-incubation for } \\
30 \text { min, evacuation } \\
\text { for } 20 \mathrm{~s}, 85-\mu \mathrm{m} \\
\text { Car } / \text { PDMS at } 40{ }^{\circ} \mathrm{C} \\
\text { for } 30 \mathrm{~min} \\
\end{array}$ & - & $0.04-4$ & $\begin{array}{l}0.9912- \\
0.9938\end{array}$ & $<4.7$ & This study \\
\hline
\end{tabular}

\section{Figures}

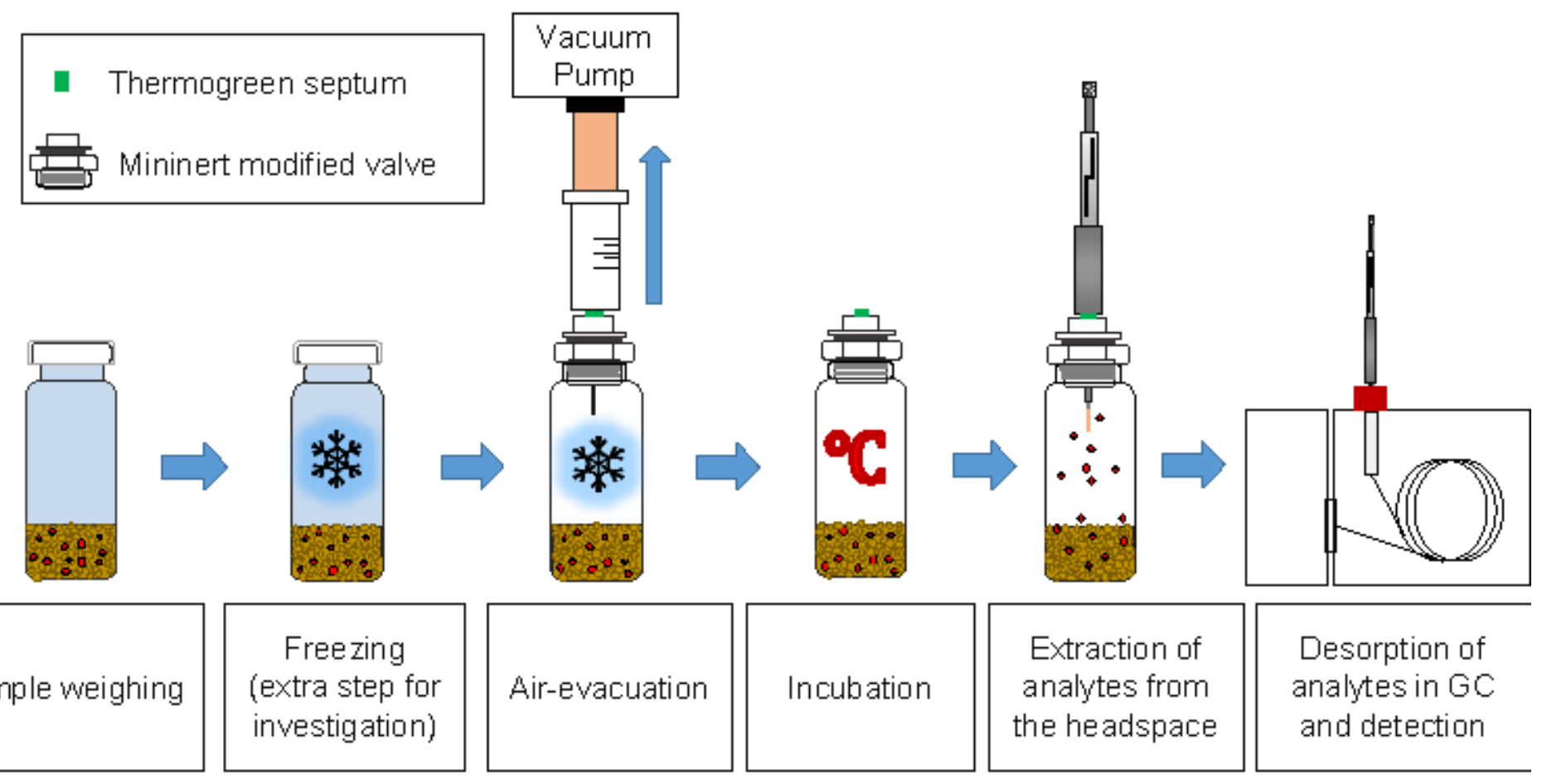


Vac-HSSPME procedure for sand samples

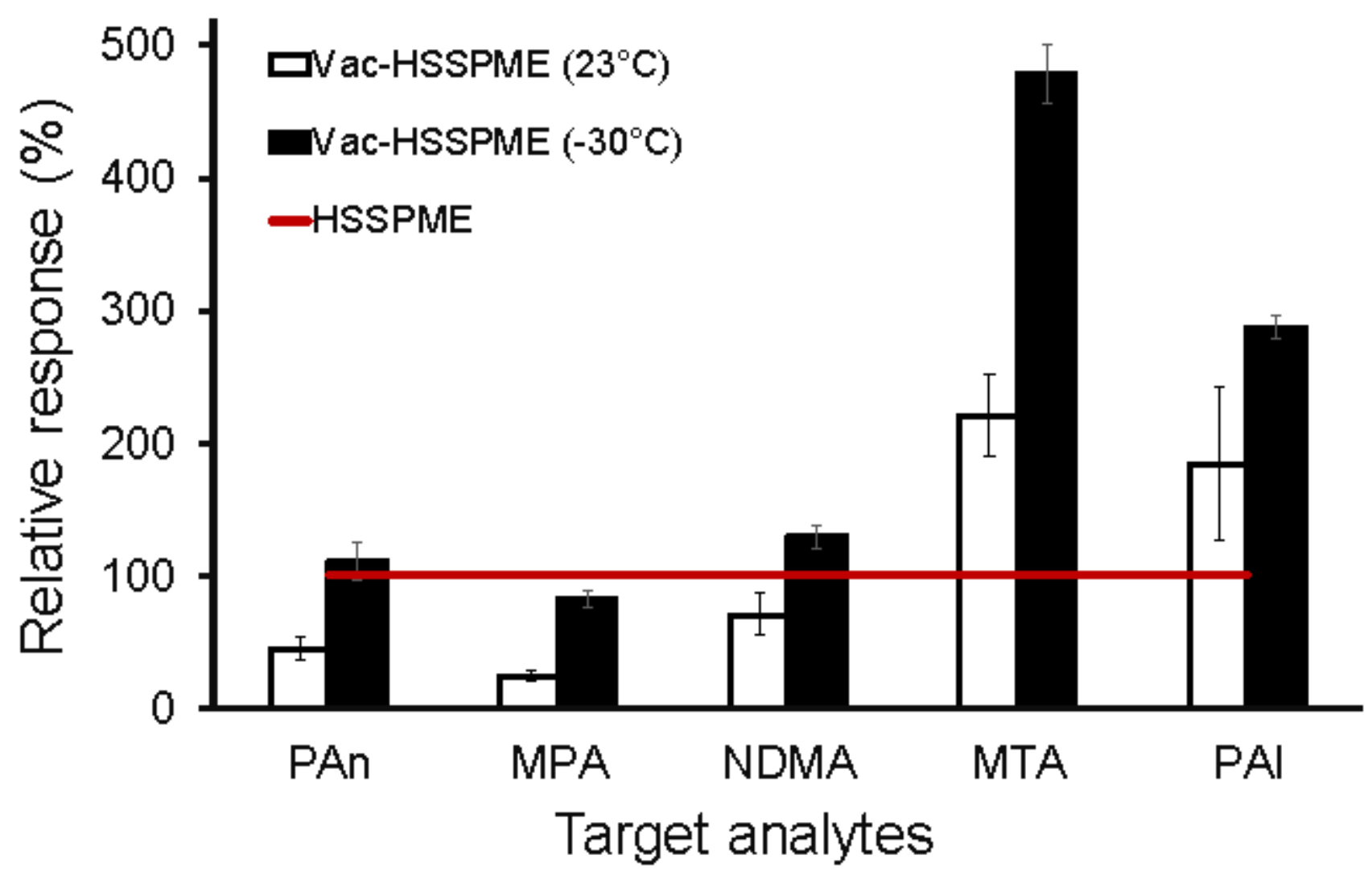

Figure 2

Effect of air-evacuation temperature on UDMH TPs responses by Vac-HSSPME in comparison with HSSPME. Evacuation time $120 \mathrm{~s}$, incubation time $30 \mathrm{~min}$, extraction time $30 \mathrm{~min}$, Car/PDMS fiber 


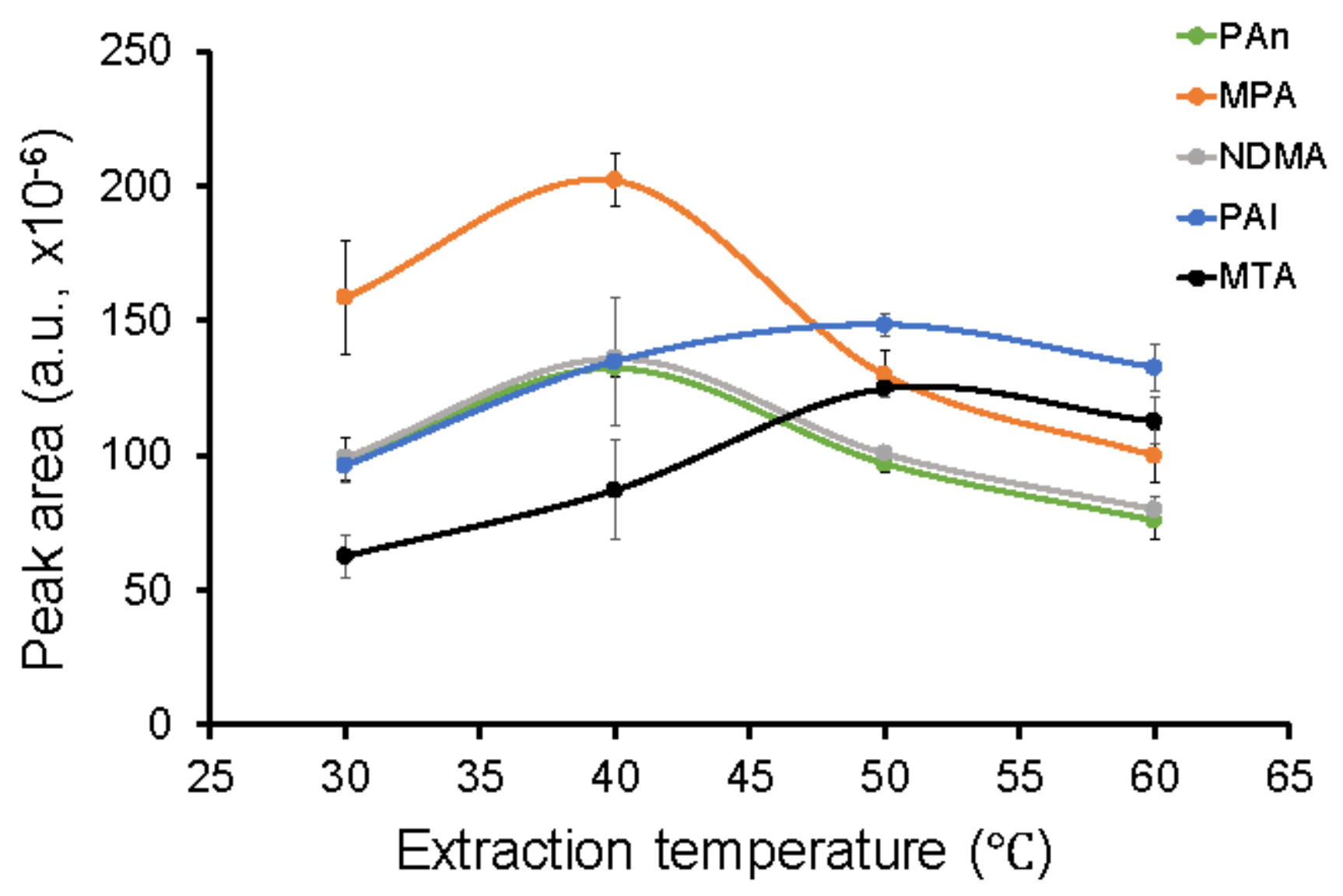

Figure 3

Effects of extraction temperatures on UDMH TPs responses by 30-min Vac-HSSPME of sand samples (air-evacuated at $-30^{\circ} \mathrm{C}$ for $120 \mathrm{~s}$, incubated for $30 \mathrm{~min}$, Car/PDMS fiber)
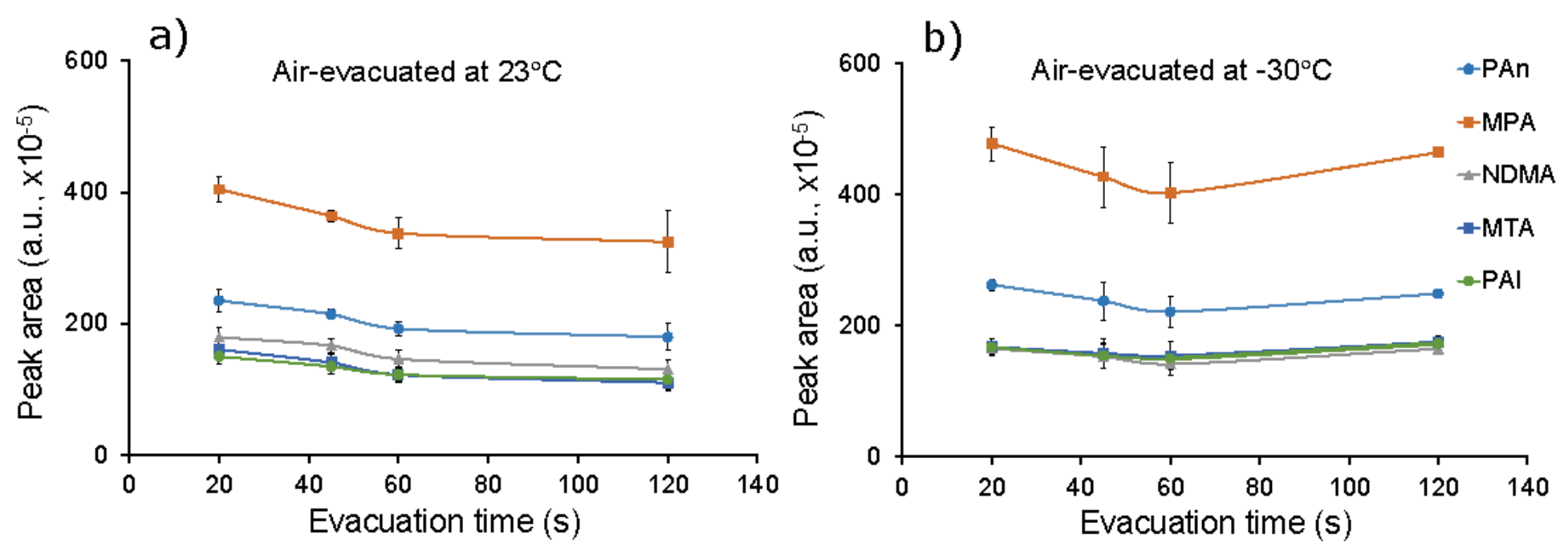

Figure 4

Effect of evacuation time at sample temperatures $23^{\circ} \mathrm{C}$ (a) and $-30^{\circ} \mathrm{C}$ (b) on UDMH TPs responses after Vac-HSSPME at $40^{\circ} \mathrm{C}$ for 30 min using Car/PDMS fiber 


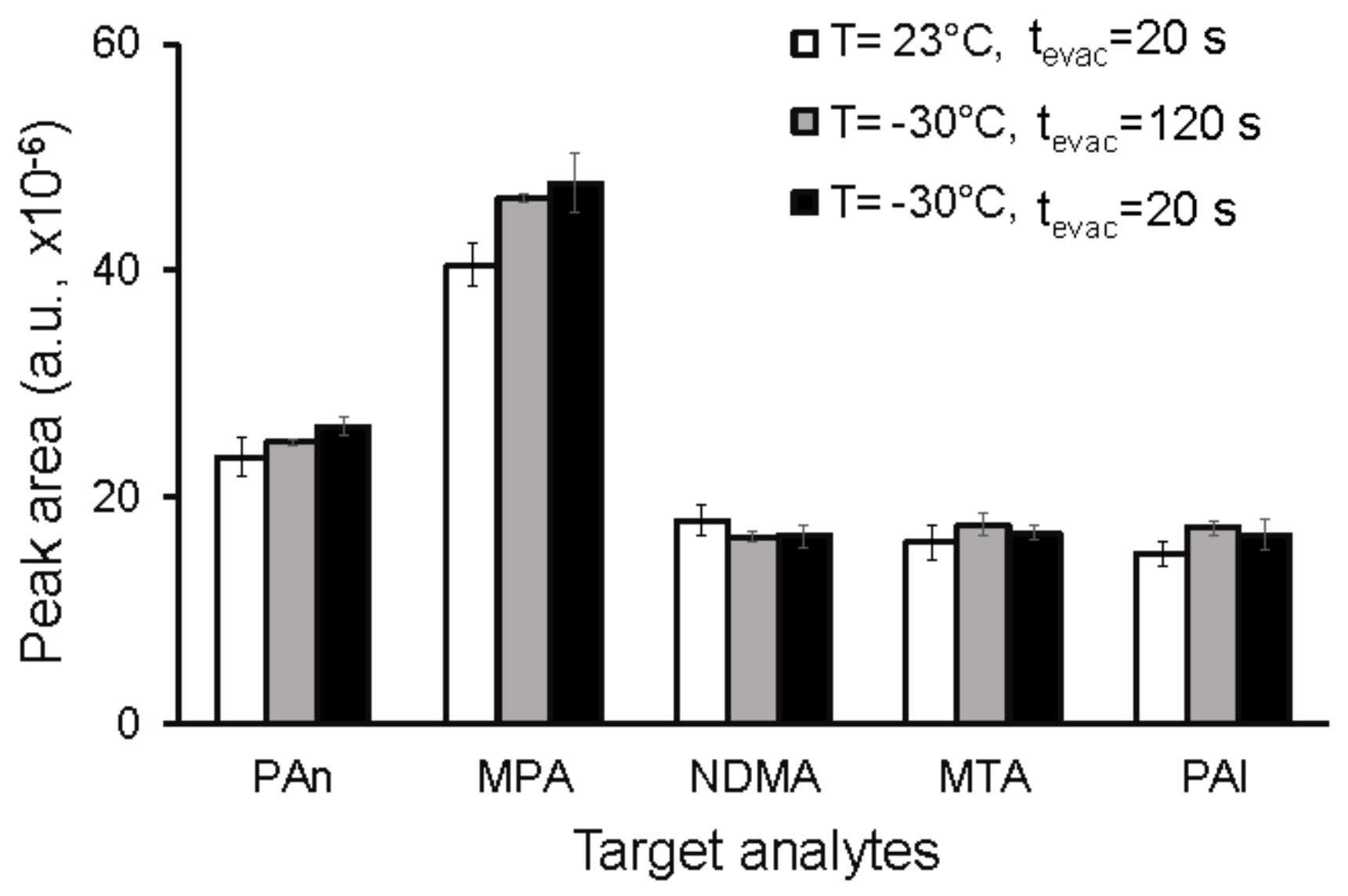

Figure 5

Effects of air-evacuation time and temperature on response of analytes (extraction temperature $40^{\circ} \mathrm{C}$, incubation time $30 \mathrm{~min}$, extraction time $30 \mathrm{~min}$, Car/PDMS fiber) 


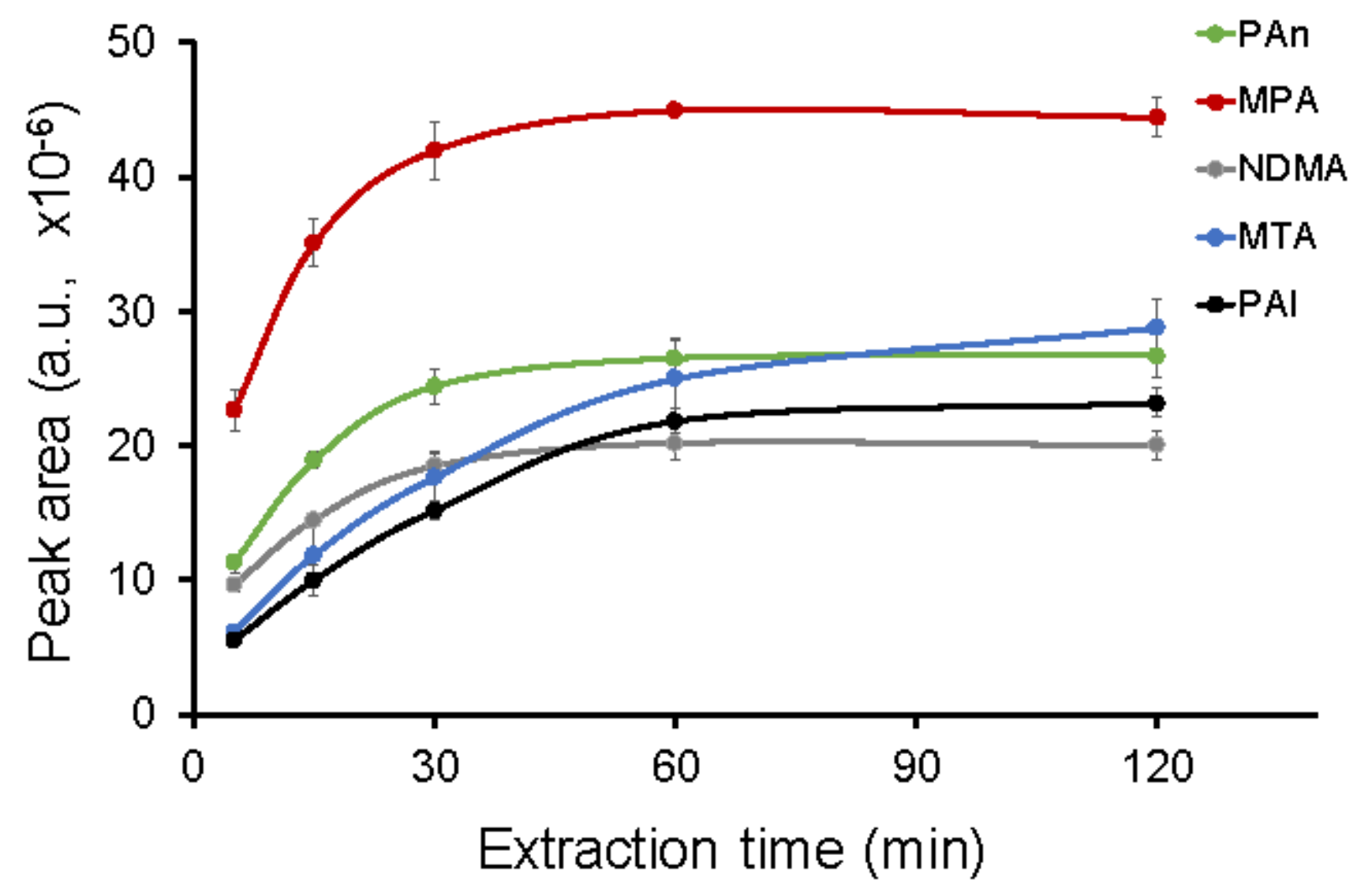

Figure 6

Effects of extraction time on UDMH TPs responses. Tevac $=23^{\circ} \mathrm{C}$, tevac $=20 \mathrm{~s}, \mathrm{~T}=40^{\circ} \mathrm{C}$, tinc $=30 \mathrm{~min}$, Car/PDMS fiber

\section{Supplementary Files}

This is a list of supplementary files associated with this preprint. Click to download.

- Fig.S1.pdf

- Fig.S2.pdf

- SMFigurecaptions.docx

- SupMat.docx 